\title{
Milestones in Bacillus subtilis sporulation research
}

\author{
Eammon P. Riley ${ }^{1}$, Corinna Schwarz ${ }^{2}$, Alan I. Derman ${ }^{2}$ and Javier Lopez-Garrido ${ }^{2, *}$ \\ ${ }^{1}$ Division of Biological Sciences, University of California, San Diego, La Jolla, CA, USA. \\ 2 Max Planck Institute for Evolutionary Biology, Plön, Germany. \\ * Corresponding Author: \\ Javier Lopez-Garrido, August-Thienemann-Str. 2, 24306 Plön, Germany; Phone: +49 4522763 216; \\ E-mail: lopezgarrido@evolbio.mpg.de
}

\begin{abstract}
Endospore formation has been a rich field of research for more than a century, and has benefited from the powerful genetic tools available in Bacillus subtilis. In this review, we highlight foundational discoveries that shaped the sporulation field, from its origins to the present day, tracing a chronology that spans more than one hundred eighty years. We detail how cell-specific gene expression has been harnessed to investigate the existence and function of intercellular proteinaceous channels in sporulating cells, and we illustrate the rapid progress in our understanding of the cell biology of sporulation in recent years using the process of chromosome translocation as a storyline. Finally, we sketch general aspects of sporulation that remain largely unexplored, and that we envision will be fruitful areas of future research.
\end{abstract}

doi: 10.15698/mic2021.01.739

Received originally: 17.07.2020;

in revised form: 21.10.2020,

Accepted 03.11.2020,

Published 27.11.2020.

Keywords: Bacillus subtilis, sporulation, genetics, SpollIE, SpolllA, SpollQ, sporulation history.
Abbreviations:
SASP - small acid-soluble protein, $S p o^{-}$- asporogenous and oligosporogenous mutants, $S_{\text {Spo }}^{+}$- sporulating strains, SRS - SpolIIE Recognition Sequence, TCA - tricarboxylic acid, TZM - 2,3,5-triphenyltetrazolium chloride.

\section{INTRODUCTION}

Since their discovery, bacterial endospores (a.k.a. spores) have attracted the attention of the scientific community and, at times, even the general public. This should not come as a surprise, as some properties of endospores could well be in the headlines of the popular press. Bacterial endospores are among the most resilient cell-types known, and can survive for very long periods of time without any nutrients. In fact, it has been claimed that viable endospores were isolated from the gut of extinct bees buried in Dominican amber more than 25 million years ago [1], evoking the imagery of Jurassic Park [2]. Furthermore, the use of Bacillus anthracis (anthrax) spores in biological warfare and, more recently, in bioterrorist attacks has brought the bacterial spore to the attention of modern society [3]. The study of endospore formation, however, is full of fascinating discoveries that, while subtle enough to escape the attention of the mainstream media, have contributed to shape our current perception of bacterial cells. This review aims to discuss some of the key findings that have shaped the sporulation field, through the lens of bacterial genetics.

\section{A BRIEF HISTORY OF ENDOSPORE FORMATION}

Arguably the most important milestone in endospore research was the actual discovery of endospores. The first reported observation of bacterial endospores dates back to 1838, when Christian Gottfried Ehrenberg noted refractile bodies inside bacterial cells [4]. It was not until nearly four decades later that endospores started to be characterized in seminal studies by Ferdinand Cohn and Robert Koch. Cohn initiated the study of the resistance properties of spores with the observation that $B$. subtilis spores survive periods of boiling [5]. Koch, in collaboration with Cohn, followed the sporulation-germination cycle in $B$. anthracis [6], and realized that spores and vegetative cells are different cellular forms of the same bacterial species, and that cells can interconvert between these two forms, from vegetative cells to spores via sporulation, and from spores to vegetative cells via germination. Their hand-drawn sketches of these processes are shown in Fig. 1.

At the same time, John Tyndall independently postulated the existence of latent bacterial forms able to survive extreme temperatures. He described a sterilization technique (now designated "tyndallization") that eradicates 
A

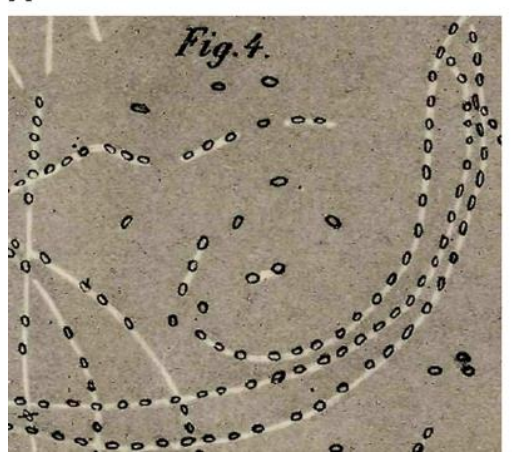

B

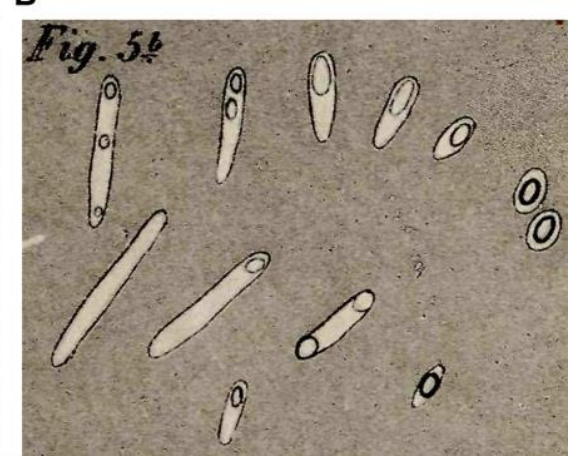

FIGURE 1: Early depictions of sporulation and germination in Bacillus spp. In one of his most well-known studies [6], Robert Koch investigated the etiology of anthrax. (A) Koch followed the sporulation process in $B$. anthracis. He placed a slice of spleen containing the Bacillus into cow sera or aqueous humor, and incubated the specimens at $35-37^{\circ} \mathrm{C}$ in an incubator that he himself had constructed. During the incubation, he observed the cells growing into string-like structures. After 10-15 h, these strings contained light refracting bodies, which he identified as spores. Koch depicted the structures in this sketch and likened them to fragile strings of pearls. The strings gradually decomposed, the spores were released and sank to the bottom of the droplet where they accumulated and could be kept for weeks. (B) Koch followed spore germination and outgrowth, and determined that spores can form viable cells. He fixed dried spores on a slide and incubated the sample with aqueous humor. After 3-4 hours, he observed various stages of germination and outgrowth, which are depicted in Cohn's sketch. Koch described spores as egg-shaped structures, enclosed by a thin layer of protoplasm that he called bright matter. He hypothesized that during outgrowth this bright matter stretched and became the vegetative cell, whereas the spore remained at one cell pole, lightened, and shrank, before it dissociated and disappeared. He proposed that the spore core consists of an oily substance necessary for the cell to resume vegetative growth.

spores from culture media through the application of intermittent heating periods that kill vegetative cells, interspersed with periods of no heat that permit the spores that survive to germinate into vegetative cells, which are then killed during subsequent heating periods [7].

Throughout the next few decades, researchers attempted to characterize the process of endospore formation in different bacterial species, but it was difficult for them to achieve a unified understanding due to the limitations of the optical microscopy and staining methods available at that time $[8,9]$. Some researchers, led by Koch, thought that spores were formed through the growth of a single refractile granule inside the cytoplasm of the vegetative cell [6]. A related model postulated that spores were not the result of the growth of a single granule, but of the fusion of multiple sporogenic granules inside the vegetative cell [10]. These putative sporogenic granules were probably cytoplasmic inclusion bodies that are present in various species of endospore forming bacteria, and are unrelated to spore formation. A different model, which comports better with our current perception of endospore formation (see below), proposed that spores were formed through the condensation of part of the vegetative cell protoplasm, which gained refractility over time [11]. A shared feature of these models, however, was that spore formation happened close to a single cell pole.

The advent of electron microscopy allowed for a more comprehensive cytological model for sporulation to be developed. In the late 1950's and early 60's, Young and Fitz-James provided detailed cytological descriptions of endospore formation in Bacillus cereus [12, 13]. Electron microscopy studies on sporulation in other Bacillus and Clostridium species were published shortly thereafter [14$16]$. By the mid 60's, the field had achieved a consensus view of the cytological transformations leading to endospore formation, which are highly conserved among different species.
In 1965, Antoinette Ryter defined six different stages of sporulation [17], based on her own studies of $B$. subtilis and on those of Young and Fitz-James in B. cereus, and this classification was later expanded to eight stages $[18,19]$. An up-to-date description of the different stages in $B$. subtilis, including details derived from fluorescence microscopy and genetic studies, is shown in Fig. 2. It is important to note that this classification represents discrete cytological steps of a process that is actually continuous. Thus, not only do several steps occur concomitantly, but also details about the transition between different stages are often neglected. For example, the transition between stages II and III happens through a phagocytosis-like process called engulfment, in which the membrane of the mother cell migrates around the forespore, generating the cell within a cell that is a hallmark of endospore formation (Fig. 2); the synthesis of the different spore layers is also gradual and starts shortly after polar septation (Fig. 2) [20]. Nevertheless, the classification proposed by Ryter represents a conceptual framework that facilitated the subsequent genetic dissection of spore formation.

\section{B. SUBTILIS AND THE GENETIC ANALYSIS OF} SPORULATION MUTANTS

During the first half of the $20^{\text {th }}$ century, sporulation was studied simultaneously in different bacterial species. Two major discoveries, however, positioned $B$. subtilis to be the ideal model system for characterizing the process of sporulation during the second half of the century: in 1958 John Spizizen reported that $B$. subtilis can be transformed with DNA [21]; shortly thereafter, Thorne and Takahashi independently isolated phages capable of mediating generalized transduction in the same organism [22-25]. These powerful tools opened new avenues for genetic studies, and several laboratories turned their attention to $B$. subtilis to perform thorough genetic analyses of sporulation. 

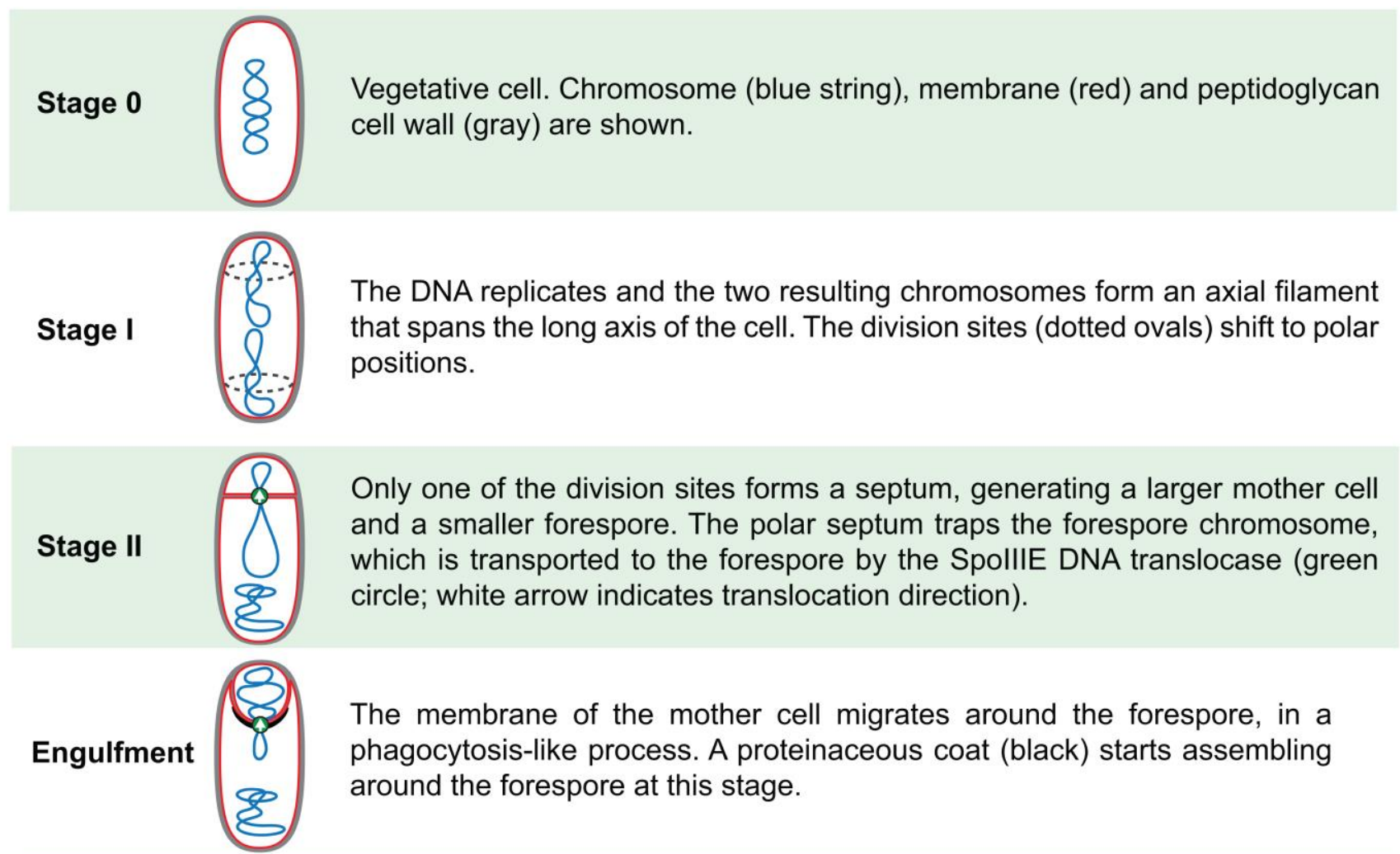

The membrane of the mother cell migrates around the forespore, in a phagocytosis-like process. A proteinaceous coat (black) starts assembling around the forespore at this stage.

After engulfment, the forespore is enclosed within the mother-cell cytoplasm,
delimited by two membranes: an inner membrane that is the original forespore
membrane, and an outer membrane derived from the mother cell engulfing
membrane.

FIGURE 2: Sporulation stages in B. subtilis. 
Mutants unable to form endospores (asporogenous), or with significantly reduced ability to form spores (oligosporogenous) have been reported for different species of endospore-forming bacteria ever since the inception of sporulation research [26]. The defining characteristic of oligosporogenous mutants is that the spores produced by them yield vegetative cells with equally low ability to produce spores. In contrast, asporogenous mutants, by definition, do not form viable spores, unless they accumulate secondary mutations that suppress the asporogenous phenotype. Such spores yield vegetative cells with significantly increased ability to form new spores compared to the asporogenous parental strain. For simplicity, we will refer to both asporogenous and oligosporogenous mutants as $\mathrm{Spo}^{-}$, and strains able to sporulate efficiently will be referred to as $\mathrm{Spo}^{+}$.

Researchers quickly devised simple, forward genetic screens to isolate $\mathrm{Spo}^{-}$mutants in large numbers, and mapped the mutations using classical genetic methods such as transformation and transduction [27, 28]. Those studies were facilitated by the development of simple tests to distinguish $\mathrm{Spo}^{+}$and $\mathrm{Spo}^{-}$strains. Spo mutants form white colonies in certain rich media, whereas strains able to sporulate efficiently form brown colonies. The brown color is due to the accumulation of a pigment whose synthesis requires a component of the spore coat, $\operatorname{Cot} A[29$, 30]. Secondly, the heat resistance of the spores provides a definitive test to distinguish $\mathrm{Spo}^{+}$and $\mathrm{Spo}^{-}$strains [31]. Determining the linkage between mutations conferring the $\mathrm{Spo}^{-}$phenotype and different markers in the chromosome led to the understanding that there are multiple sporulation (spo) loci, scattered around the chromosome [27, 28, 32-34].

The initial analysis of $\mathrm{Spo}^{-}$mutants indicated that sporulation was blocked at different stages in different $\mathrm{Spo}^{-}$ mutants [31], suggesting that each sporulation stage was controlled by a dedicated set of genes. This was formally confirmed in 1966, when Ryter and collaborators performed a cytological characterization of $B$. subtilis strains carrying different spo mutations using electron microscopy, and classified them according to the stage at which sporulation was blocked [18]. This study led to the establishment of a specific nomenclature for the spo loci that was formal- ized in a classic review by Piggot and Coote in 1976 [19]. The spo loci were defined as those, that when mutated, impaired the ability of the cell to form spores, without having a noticeable effect on vegetative growth. The loci were classified into different categories (spoO, spoll, spolll, spolV, and so on), according to the stage at which sporulation was blocked in the mutants (Fig. 2). No distinction was made between stages 0 and $\mathrm{I}$, and mutations that caused blockage in either stage were globally referred to as spo0. A capital letter was used to distinguish different loci, mutations in which produced blockages at the same stage. Thus, for example, spollIA and spoIIIE refer to two distinct loci that, when mutated, produce a blockage at stage III. In some cases, it was later discovered that a specific locus was actually an operon containing several genes. In those cases, the different genes of the operon were assigned a second capital letter (for example, the spolllA locus actually consists of an operon of at least eight genes, which are named in order from spollIAA to spollIAH).

In addition to the spo genes, three more developmental gene categories were described: ger, cot and ssp (Fig. 3). Many ger genes were identified in elegant genetic screens for mutations that rendered spores unable to germinate properly [35-40]. These screens relied on an agar plate assay in which colonies formed by mutagenized cells were treated with heat or chloroform vapor to kill vegetative cells [35]. The remaining spores were then overlaid with agar containing two key components: (i) nutrients to induce germination, and (ii) 2,3,5-triphenyltetrazolium chloride (TZM), which turns red when reduced by metabolically-active cells. Spores are metabolically dormant, and are unable to reduce TZM to produce the red pigment, but upon germination become metabolically active and can reduce TZM to give the colonies a pink coloration. Colonies containing germination-deficient spores fail to reduce TZM, and therefore, do not produce the red pigment. While some of the ger genes identified in germination screens encode proteins involved exclusively in germination (for example, the genes encoding germinant receptors, such as those in the gerA and ger $B$ operons), others encode proteins that are actually required for proper spore development, generating some overlap between ger and spo genes (for instance, gerM is required for proper sporulation, but

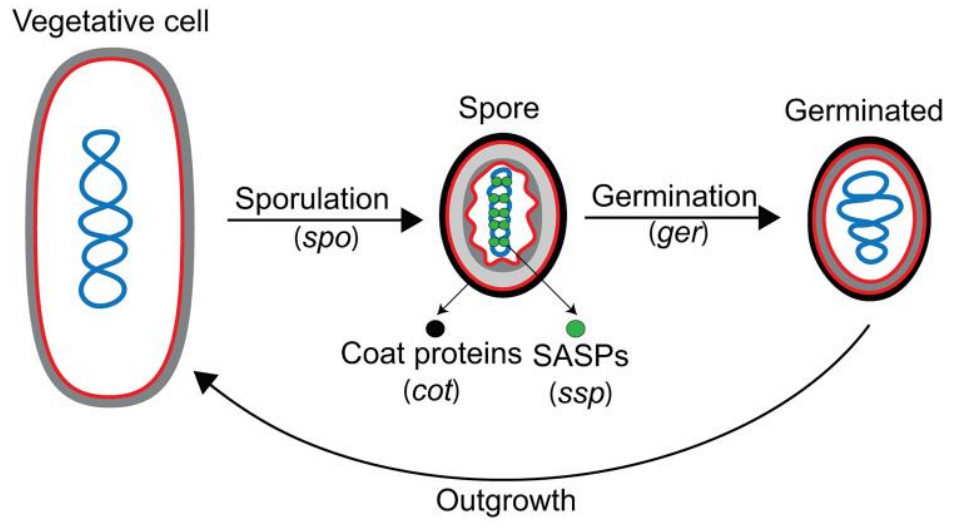

FIGURE 3: Developmental loci in B. subtilis. Diagram of the sporulation-germination cycle, with the different classes of developmental loci noted (in parentheses). The spo loci are required for spore formation, but not for vegetative growth. The ger loci are required for proper spore germination. After germination, metabolism is reactivated and the spore transforms into a growing vegetative cell in a process called outgrowth, which is thought to depend on the same pathways that control vegetative growth. The cot and ssp loci were identified after the isolation and characterization of coat and small acid-soluble proteins (SASPs), respectively, from spores. In addition to the these categories, there are hundreds of developmentally-regulated genes whose roles in sporulation and germination are not yet understood. Membranes, red; DNA, blue; cell wall, gray; spore cortex, light gray; spore coat, black; SASPs, green circles. 
it was first identified in a screen for germination mutants $[41,42])$.

The two major remaining categories of developmental genes, cot (for coat) and ssp (for spore-specific protein), were identified by reverse genetics, after the isolation and biochemical characterization of coat proteins and small acid-soluble proteins (SASPs) [29, 43-47] from spores, respectively (Fig. 3). SASPs are abundant spore proteins that saturate and protect the spore chromosome [45]. Since individual SASPs and most coat proteins are dispensable for $B$. subtilis sporulation under standard laboratory conditions $[29,46,48,49]$, they were missed in the genetic screens that led to the identification of spo genes.

The discovery and characterization of developmental genes accelerated after the rise of DNA cloning and sequencing technology. Researchers were able to clone spo genes by selecting for chromosomal DNA fragments that complemented the respective spo mutations. From these clones, lacZ fusions were generated, and these in turn allowed for the study of the spo genes in vivo. New genetic tools, such as Tn917-based transposition mutagenesis [5052] and integrational plasmid vectors [52-55], further facilitated the identification and manipulation of spo loci. During the late 1970's and 80's, many developmental loci were cloned and sequenced, their expression characterized, and the role of the proteins they encode started to be deciphered.

\section{CELL-SPECIFIC GENE EXPRESSION}

Three main conclusions arose from the initial genetic analysis of sporulation: first, most developmental genes are not expressed in growing cells, and their expression is induced at different times during sporulation; second, there is a dependency hierarchy in developmental gene expression, such that the expression of genes that participate in later events in the sporulation pathway tends to depend on the expression of genes that participate in earlier events; third, the majority of the sporulation genes are expressed in only one of the two cells required to form a spore, either the mother cell or the forespore. This last conclusion was achieved by using fractionation techniques to separate forespore and mother-cell protoplasms [56-58], and by the implementation of genetic strategies to determine the cell in which different spo genes were required $[59,60]$. In one such genetic strategy, developed by Lencastre and Piggot [59] and illustrated in Fig. 4, Spo ${ }^{-}$mutants were transformed with genomic DNA from the wild-type $\left(\mathrm{Spo}^{+}\right)$strain at the start of sporulation, thereby rendering the $\mathrm{Spo}^{-} \mathrm{mu}-$ tants capable of forming heat-resistant spores. The parental Spo- mutants fell into two categories, depending on the ability of the resultant spores to produce additional spores following germination: mutants in the first category produced spores that were homogeneously $\mathrm{Spo}^{+}$; mutants in the second category produced a heterogeneous population of $\mathrm{Spo}^{+}$and $\mathrm{Spo}^{-}$spores. The spo genes mutated in the first category of parental strains were inferred to be required in the forespore, and the ones mutated in the second were inferred to be required in the mother cell. The logic under- lying this interpretation is as follows (Fig. 4): of the two cells required to form a spore, only the forespore retains its chromosome in the mature spore, since the mother cell lyses upon sporulation completion (Fig. 2). Thus, spo genes required in the forespore must be complemented in the forespore chromosome and the wild-type version of the gene will therefore always present in mature spores, and these will give rise to a homogenous population of $\mathrm{Spo}^{+}$ transformant spores. But if a spo gene is required in the mother cell and not in the forespore, then sporulating cells in which only the mother-cell chromosome is transformed with the wild-type allele will be able to form mature spores, but the non-transformed forespore chromosome would still contain the mutated version of the spo gene, and the spores would remain $\mathrm{Spo}^{-}$.

Results from these biochemical and genetic analyses underscored that different genetic programs were activated in the two cells, at different times during sporulation. From here, the focus moved on to deciphering the genetic regulation of sporulation.

In 1969, it was discovered that bacterial RNA polymerases contain a factor, called Sigma $(\sigma)$, that is necessary for promoter recognition and transcription initiation [61, 62]. This finding led researchers to hypothesize the existence of alternative $\sigma$ factors, which could direct RNA polymerase to specific subsets of promoters. The existence of such alternative $\sigma$ factors was first demonstrated in $B$. subtilis phage SP01 [63], which encodes $\sigma$ factors that drive expression from middle and late phage promoters. The first bacterial alternative $\sigma$ factor to be discovered was $\sigma^{37}$ [64], a general-stress response $\sigma$ factor of $B$. subtilis. Initially, the name of the different $\sigma$ factors was based on their molecular weight, in $\mathrm{kDa}$. Thus, $\sigma^{37}$ was $\sim 37 \mathrm{kDa}$, as determined by the apparent size of the purified protein in an acrylamide gel. However, the discovery of alternative $\sigma$ factors with similar sizes or that migrated aberrantly in acrylamide gels accelerated over the following years, which led researchers in the $B$. subtilis field to replace the molecular weight designation with a letter reflecting order of discovery $[65,66]$. Thus, $\sigma^{37}$ was renamed $\sigma^{B}$, the name by which it is commonly known today, and the genes encoding the $\sigma$ factors were named sig followed by their corresponding letter.

Shortly after the discovery of $\sigma^{B}$, it was shown that the sporulation regulatory program also relies on alternative $\sigma$ factors that are activated in the mother cell or in the forespore at different developmental stages. The first sporulation-specific $\sigma$ factor to be discovered was $\sigma^{\mathrm{E}}$ (originally referred to as $\sigma^{29}$ ) [67]. $\sigma^{\mathrm{E}}$ was discovered using predominantly biochemical and molecular biology techniques [67]. The protein was isolated from RNA polymerase purified from sporulating cultures, and was shown to change the promoter specificity of RNA polymerase in vitro. Not surprisingly, it was subsequently shown that $\sigma^{\mathrm{E}}$ was encoded by a previously identified spo locus, spollGB (later renamed as $\operatorname{sig} E)[68,69]$. After $\sigma^{\mathrm{E}}$, three additional sporulation $\sigma$ factors were identified by means of both sequence similarity with previously identified $\sigma$ factors, and in vitro transcription assays of sporulation genes: $\sigma^{\mathrm{F}}[70,71], \sigma^{\mathrm{G}}[72-$ 


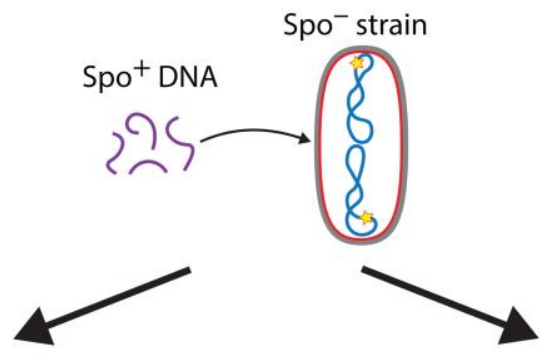

spo gene required in forespore (FS)

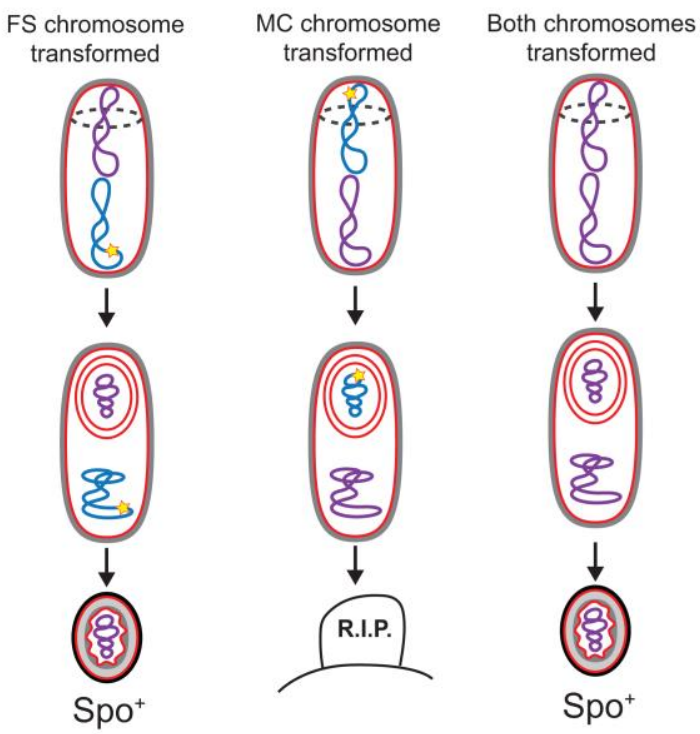

All viable spores are Spo+ spo gene required in mother cell (MC)

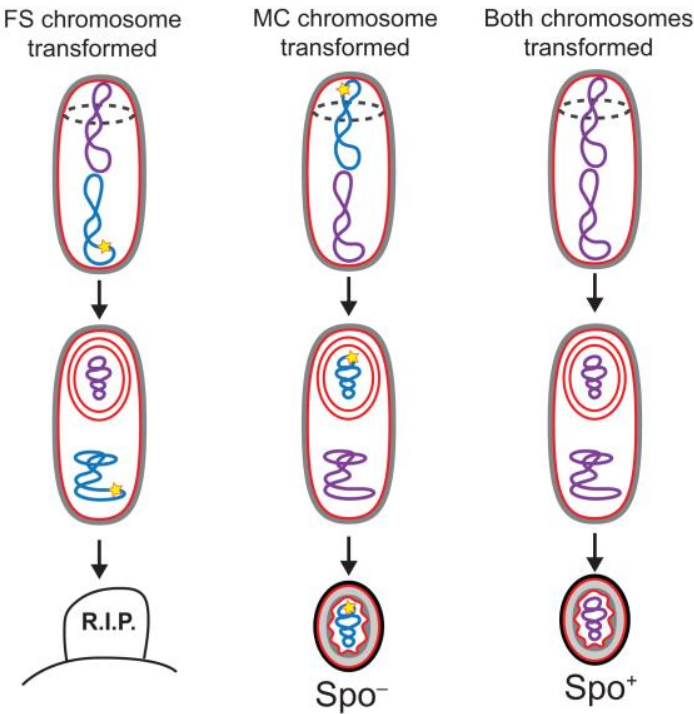

Viable spores are $\mathrm{Spo}^{-}$or $\mathrm{Spo}^{+}$

FIGURE 4: Genetic strategy to identify the cell in which a spo gene is required. A Spo- strain with a mutation in a known spo gene (yellow star) is depicted in Stage I (see Fig. 2) with its two chromosomes, one that will be packed into the forespore (upper chromosome) and one that will remain in the mother cell and be destroyed when the mother cell lyses (lower chromosome). The strain is transformed with genomic DNA from a Spo strain at the onset of sporulation. Transformed chromosomes are drawn in purple, non-transformed chromosomes, in blue. Either or both chromosomes are capable of being transformed to $s p o^{+}$. If the spo gene is required in the forespore (left panel), transformation of the forespore chromosome to $s p o^{+}$rescues the process and generates spores that can germinate and go on to sporulate again (left). But transformation of the mother-cell chromosome to spo ${ }^{+}$with no accompanying transformation of the forespore chromosome leaves the forespore chromosome $s p o^{-}$so the cells cannot complete the process, and no spores are produced (center). Hence only Spo ${ }^{+}$ spores are generated if the spo gene is required in the forespore. If the spo gene is required in the mother cell (right panel), transformation of the mother-cell chromosome to $s p o^{+}$rescues the process (center and right), but only if the forespore chromosome is transformed as well will the spores that are produced be able to germinate into cells that can go on to sporulate again (right). Hence, both Spo ${ }^{+}$and Spo ${ }^{-}$spores can be generated if the spo gene is required in the mother cell.

74] and $\sigma^{\mathrm{K}}[75]$. In B. subtilis, the activation of the different sporulation $\sigma$ factors follows a hierarchical order in which different $\sigma$ factors are sequentially activated in alternating cellular compartments, and the activation of a later factor depends on the activation of the previous one (Fig. 5): first, $\sigma^{\mathrm{F}}$ becomes active in the forespore shortly after polar septation, followed by $\sigma^{\mathrm{E}}$ in the mother cell. Roughly coincident with engulfment completion, $\sigma^{G}$ is activated in the forespore and, finally, $\sigma^{\mathrm{K}}$ is activated in the mother cell. The variety of mechanisms involved in the sequential activation of these $\sigma$ factors includes phosphorelays, proteolytic processing, and even a gene splicing event [76-79].
After the discovery of the sporulation-specific $\sigma$ factors, many of the developmental genes previously identified were assigned to different regulons, depending on the $\sigma$ factor controlling their expression. Microarray technology allowed researchers to discover additional genes under the control of sporulation $\sigma$ factors $[80,81]$. Together the cellspecific $\sigma$ factors control the expression of more than 500 different genes [82, 83], the majority of which are not expressed during vegetative growth. Over the course of the past few decades, the study of sporulation has focused on deciphering the function of genes that are under the control of sporulation-specific $\sigma$ factors. But the functions of nearly $1 / 3$ of these genes remain a mystery, and for the 


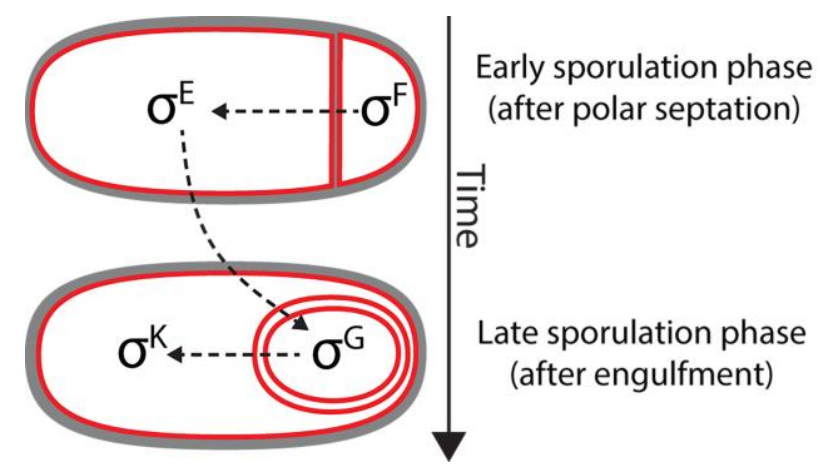

FIGURE 5: Cascade of sporulation-specific $\sigma$ factors in $B$. subtilis. Immediately after polar septation, $\sigma^{\mathrm{F}}$ is activated in the forespore. $\sigma^{\mathrm{F}}$ activation triggers an intercompartmental signaling cascade that leads to the activation of $\sigma^{\mathrm{E}}$ in the mother cell. Together $\sigma^{\mathrm{F}}$ and $\sigma^{\mathrm{E}}$ control gene expression during engulfment. Roughly coincident with the completion of engulfment, $\sigma^{\mathrm{F}}$ is replaced by $\sigma^{\mathrm{G}}$ in the forespore, which leads to the subsequent activation of $\sigma^{\mathrm{K}}$ in the mother cell. $\sigma^{G}$ and $\sigma^{K}$ control gene expression in the forespore and the mother cell, respectively, after engulfment.

majority of sporulation genes with assigned function, we have only a superficial knowledge of how specific gene products contribute to spore formation. We envision that the study of developmentally-regulated genes will continue to be a fruitful area of research for years to come.

\section{CELL-SPECIFIC GENE EXPRESSION AS A GENETIC TOOL}

Beyond its central importance to the developmental program of sporulation, cell-specific gene expression has come to provide a powerful genetic tool for the study of different aspects of spore formation. After the discovery of the sporulation-specific $\sigma$ factors, many researchers carefully characterized promoters regulated by the different $\sigma$ factors (i.e. [84-92]), enabling these promoters to be coopted for expression of heterologous genes in either the mother cell or the forespore, at different developmental stages. Cell-specific gene expression has been used to study many of the fundamental features of spore formation such as the temporal compartmentalization of the different sporulation $\sigma$ factors [93], the organization of the chromosomes after sporulation initiation [94], and the transport of the forespore chromosome from the mother cell to the forespore [95-101], among other things. In order to illustrate the power of this approach, we describe three experiments that have helped to disentangle, at least partially, the function of the sporulation loci spolllA and spollQ (Fig. 6):

Mother-cell proteins encoded in the spollIA operon (which contains eight genes, spollIAA to spollIAH) together with the forespore protein SpollQ form a trans-envelope multimeric complex (henceforth $A-Q$ complexes) that spans the mother-cell and forespore membranes (Fig. 6A) $[102,103]$. Mutants lacking spolllA or spollQ are asporogenous, as they fail to activate the late forespore $\sigma$ factor, $\sigma^{G}$ $[104,105]$. Some of the SpolllA proteins show sequence and structural homology to components of various secre- tion systems from Gram-negative bacteria [103, 106-108], and one of them, SpollIAG, has been shown to form multimeric rings in vitro $[109,110]$, leading to the proposal that $A-Q$ complexes constitute proteinaceous channels that connect the mother cell and the forespore, through which molecules required for $\sigma^{G}$ activation might be transferred between the two cells. Meisner and collaborators developed a compartmentalized biotinylation assay to test this idea (Fig. 6A) [111]. The authors used mother cell- and forespore-specific promoters to express the gene encoding E. coli biotin ligase (birA) in either cell, and fused biotin acceptor peptides to the extracellular domains of $A$ and $Q$ proteins. They found that BirA produced in the forespore could biotinylate the extracellular domain of SpollIAH, which supported the idea that A-Q complexes are channels that are open at least on the forespore side.

In a separate study, Camp and Losick took advantage of cell-specific gene expression to study whether A-Q channels were specifically required for $\sigma^{G}$ activation, or if they also played a role in the expression of $\sigma^{G}$-independent genes (Fig. 6B) [112]. They monitored the activity of the heterologous RNA polymerase, T7 RNAP, when produced in the forespore from a $\sigma^{F}$-dependent promoter by placing a lacZ gene under the control of a T7 RNAP-dependent promoter. In the presence of $A-Q, \beta$-galactosidase activity could be detected at the onset of sporulation, and it increased gradually over time until it reached a plateau that was maintained throughout spore formation. In mutants lacking functional $A-Q$ complexes, $\beta$-galactosidase activity was also detected at the onset of sporulation, but dropped off later in sporulation, at roughly the time when $\sigma^{G}$ would be normally activated. These observations indicated that A$Q$ plays a general role in regulating forespore gene expression at late sporulation stages, rather than affecting $\sigma^{G}$ activity specifically. The authors proposed that $A-Q$ channels constitute a feeding tube through which the mother cell provides metabolic resources to the forespore in order to maintain forespore biosynthetic activities at late sporulation stages [112].

We have recently accumulated more evidence that the mother cell nurtures the forespore, by implementing a cellspecific protein degradation system that also relies on cellspecific gene expression (Fig. 6C and D) [113, 114]. The system uses modified ssrA* tags from $E$. coli fused to the Cterminus of target proteins [114], and the cognate $E$. coli $\mathrm{SspB}$ adaptor protein produced under the control of mother-cell or forespore-specific promoters [113] (note that $E$. coli SspB is not related to the sporulation ssp genes described previously in this manuscript; to avoid confusion, $E$. coli $\mathrm{SspB}$ will be referred to as $\mathrm{SspB}^{\mathrm{EC}}$ ). When $\mathrm{SspB}^{\mathrm{EC}}$ is produced, it binds to ssrA* and delivers the target protein to the endogenous $B$. subtilis protease ClpXP for degradation (Fig. 6C and D) [114]. We are using this platform to systematically assess the requirement of different metabolic pathways in the mother cell and in the forespore for sporulation to progress normally. Our results indicate that the tricarboxylic acid (TCA) cycle is required in the mother cell, but is largely dispensable in the forespore (Fig. 6E) [115] We have also observed that protein synthesis in the fore- 
spore requires TCA cycle activity in the mother cell, suggesting that the mother cell produces TCA cycle-derived metabolic precursors, such as amino acids, for protein synthesis in both the mother cell and the forespore (Fig. 6E) [115]. These findings indicate that mother-cell metabolic precursors are transported to the forespore to support protein synthesis, in line with the feeding tube model proposed by Camp and Losick [112].

Overall, cell-specific gene expression has been a fantastic addition to the list of genetic tools available in $B$. subtilis.
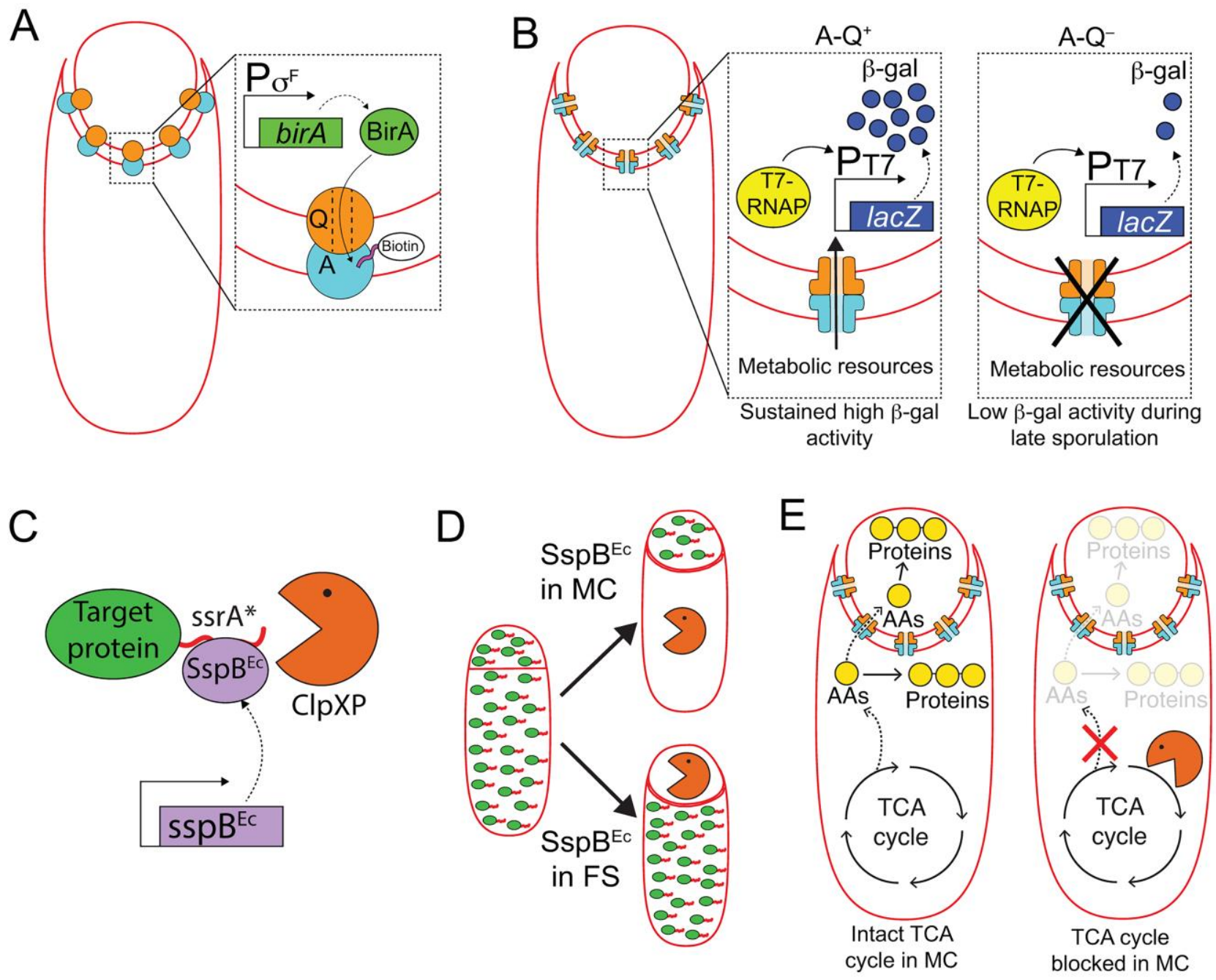

FIGURE 6: Harnessing cell-specific gene expression to study the function of A-Q complexes. (A) The forespore protein SpollQ ( $Q$, orange circle) and the mother-cell proteins encoded in the spolliA operon ( $A$, light blue circle), form trans-envelope complexes that bridge the forespore and mother-cell membranes during engulfment. Zoomed in panel: Biotin ligase (BirA, green) produced in the forespore is able to biotinylate a biotin acceptor peptide (pink) fused to the extracellular domain of the A protein, SpollIAH [111], indicating that A-Q complexes are channels (see panel B), and that the channel pore is open on the forespore side and large enough for BirA to reach the extracellular domain of SpollIAH. (B) The activity of a heterologous RNA polymerase (T7 RNAP, yellow) produced in the forespore under $\sigma^{\mathrm{F}}$ control is monitored by the accumulation of $\beta$-galactosidase ( $\beta$-gal, dark blue circles) produced through the expression of a lacZ gene under the control of a T7 RNAP-dependent promoter. In the presence of $A-Q$ channels $\left(A-Q^{+}\right.$, left zoomed in panel), sustained $\beta$-galactosidase activity is detected throughout sporulation. In the absence of $A-Q$ channels ( $A-Q^{-}$, right zoomed in panel), $\beta$-galactosidase activity drops at later sporulation stages. Camp and Losick [112] proposed that A-Q channels constitute feeding tubes through which the mother cell transfers metabolic resources to the forespore to maintain biosynthetic activities at late sporulation stages. (C) The ssrA*/SspBEc inducible protein degradation system [114]. SspB ${ }^{E C}$ (purple) binds to ssrA* (red) fused to the C-terminus of target proteins (green), and delivers the target proteins to the endogenous B. subtilis protease ClpXP (orange pacman) for degradation. (D) Cell-specific degradation of target proteins during sporulation is achieved by expressing $s s p B^{E C}$ from mother cell- or forespore-specific promoters [113]. Target proteins represented by green ovals tagged with ssrA (red line); degradation represented by orange pacman. (E) Left cell: Mother-cell TCA cycle provides metabolic precursors, such as amino acids (AAs, yellow circles), to support protein synthesis in both the mother cell and the forespore [115]. Mother-cell metabolic precursors could be transported to the forespore via A-Q channels, in keeping with the feeding tube model. Right cell: Degradation of TCA cycle enzymes in the mother cell blocks protein synthesis in both the mother cell and the forespore [115]. 
We are looking forward to seeing new creative approaches using those tools to explore the inner workings of sporulating bacteria.

\section{THE GENETIC BASIS OF CELLULAR DYNAMICS}

The study of sporulation has helped to overturn the traditional dogma that bacterial cells lack a defined internal organization owing to the absence of membrane-bound organelles. Over the last 25 years, we have obtained precise descriptions of how proteins are redistributed during sporulation to mediate dynamic cellular processes. Advances in our understanding of sporulation during this period have been driven by the development of a wealth of new imaging technologies, particularly in fluorescence microscopy, which have allowed the field of bacterial cell biology to emerge. We illustrate the rapid progress made in this field by focusing on a single protein, SpollIE.

Since the mid $20^{\text {th }}$ century, it was recognized that the two chromosomes resulting from a replication event prior to sporulation initiation are segregated during sporulation, such that one remains in the mother cell and the other is packed into the small forespore [12]. In 1994, Wu and Errington [116] reported that mutations in spollIE, one of the spo loci that was identified during the genetic analysis of sporulation mutants, prevented complete segregation of the forespore chromosome, such that only $\sim 30 \%$ of the chromosome was present in the forespore with the rest still in the mother cell (Fig. 7A). They inferred that the polar septum trapped the forespore chromosome, and that SpollIE mediated the translocation of the chromosome across the septum into the forespore.

Further studies showed that SpollIE is a membraneanchored FtsK-like protein that has a large C-terminal cytoplasmic motor domain [117] with DNA-dependent ATPase activity, that is capable of tracking along DNA in the presence of ATP [118]. More recently, in vitro studies with purified SpollIE motor domains have shown that they assemble into hexameric rings $[119,120]$, with an inner diameter large enough to accommodate a double-stranded DNA molecule [119]. Single molecule experiments using optical tweezers have allowed the characterization of the inter-subunit coordination [121] and of the mechanochemistry [122] of the hexameric rings as they move along DNA molecules, providing exquisite details of the mechanism of chromosome translocation at the molecular level.

SpollIE assembles into a translocation complex at the septal midpoint during the early stages of sporulation (Fig. 7B). This was shown first in fixed cells using immunofluorescence microscopy [117] and later in living cells with a SpollIE-GFP fusion and fluorescent membrane dyes that are compatible with live cell imaging [123] (Fig. 7B). More recently, studies of the assembly of the SpollIE translocation complex with super-resolution optical microscopy techniques [101, 124, 125] have revealed that SpollIE oligomers localize to the leading edge of the polar septum as it forms, and ultimately assemble a stable translocation complex at the septal midpoint. In mutants that produce thicker than normal polar septa, super-resolution micros- copy has made it possible to resolve two different foci within the SpolllE complex (Fig. 7C), suggesting that the complex consists of two subcomplexes of opposite polarity, one anchored to the mother cell and the other to the forespore septal membrane. Each subcomplex contains enough SpolliE monomers to assemble at least two hexameric rings [101], which would allow the two arms of the chromosome to be translocated in parallel from the mother cell to the forespore (Fig. 7D) [98].

Assembly of the SpollIE translocation complex requires that the DNA be trapped at the septum [126], and the complex is in turn required to mediate septal membrane fission while the chromosome is translocated [124]. This has led to the proposal that the mother-cell and forespore SpollIE subcomplexes pair to form a continuous channel spanning both septal membranes (Fig. 7D). In support of this idea, it has been shown that both forespore and mother-cell subcomplexes are required to keep the septal membranes separated during chromosome translocation [101]. However, the mother-cell subcomplex by itself is sufficient to mediate the transport of the chromosome into the forespore [95, 101]. If the SpollIE mother-cell subcomplex is absent, the forespore subcomplex can transport the chromosome out of the forespore and into the mother cell $[95,101]$, indicating that the SpolIIE translocation complex can, in principle, function as a bidirectional motor. During sporulation, however, the SpollIE translocation complex always transports the chromosome from the mother cell to the forespore (Fig. 7D). The mechanism that determines translocation directionality has been at least partially elucidated by means of a combination of in vivo, in vitro and in silico approaches. The motor domain of SpollIE is able to recognize specific, highly-skewed octameric sequences in the DNA called SpollIE Recognition Sequences (SRSs), which are present in each arm of the chromosome but on opposite strands [97]. Since the $B$. subtilis chromosome is circular and the two chromosome arms are trapped at the septum, the opposite orientation of SRSs on each arm might serve as a cue to determine translocation directionality. In fact, it has been shown that the interaction of SpollIE with the SRS in the orientation preferentially encountered by SpoIIIE as each chromosome arm is directed into the forespore stimulates SpollIE ATPase activity [120, $127,128]$. This might account for the direction of translocation and the simultaneous transport of both chromosome arms to the forespore.

In addition to guaranteeing that the forespore receives a full complement of genetic material, SpolllE-mediated chromosome translocation also contributes to the generation and maintenance of forespore shape during engulfment [100]. Packaging an entire chromosome into the small forespore compartment leads to a high turgor pressure, which inflates the forespore like a balloon and distends the forespore membranes (Fig. 7E).

While spollIE is among the best characterized spo loci, the field has made significant progress in the understanding of a myriad of dynamic processes associated with sporulation, such as the formation of the polar septum [129$131]$, the migration of the mother-cell membrane around 

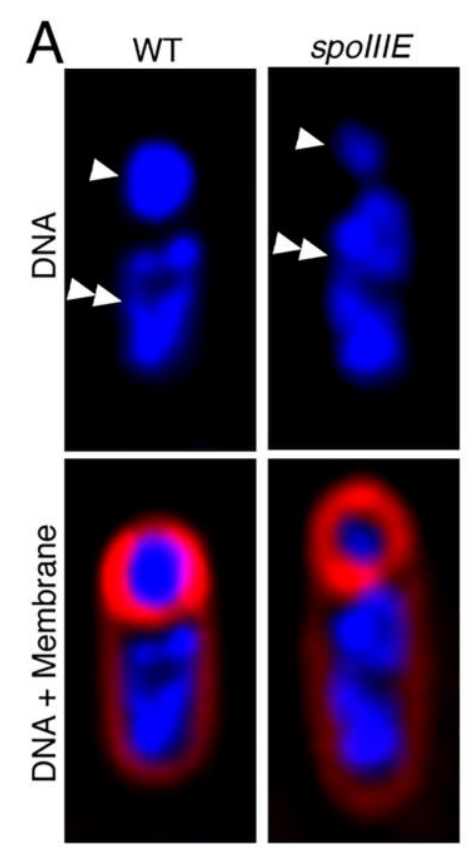
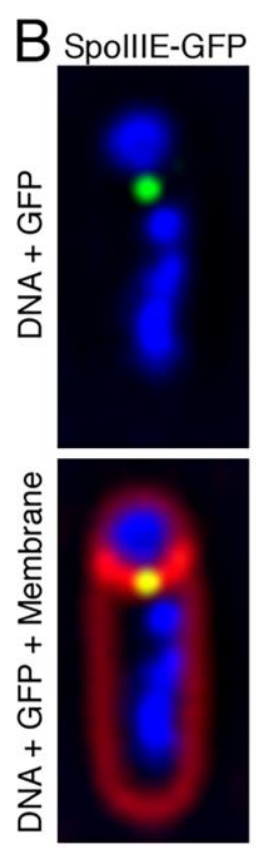

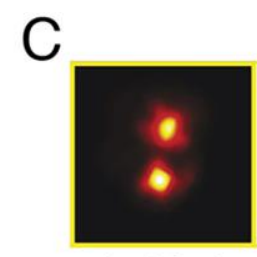

dual foci
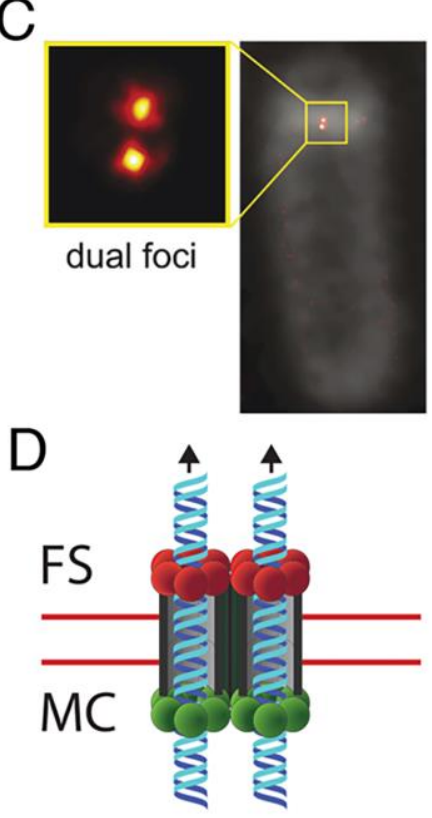
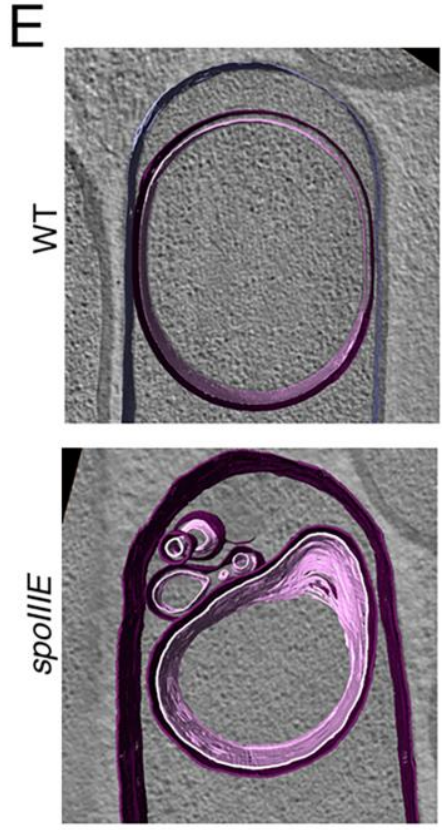

FIGURE 7: Progress in our understanding of SpollIE-mediated chromosome translocation. (A) Fluorescence microscopy images of a wildtype (WT, left) and of a spollIE mutant (spollIE, right) strain of B. subtilis. The upper panels show the DNA stained with DAPI (blue), and the lower panels the overlay of DAPI-stained DNA and the membranes stained with FM 4-64 (red). In the upper panel, forespores are indicated by single arrowheads, and mother cells by double arrowheads. Wild-type forespores contain a complete chromosome. However, forespores of spollIE mutant strains contain only $\sim 30 \%$ of a chromosome, and the rest remains trapped in the mother cell. (B) Fluorescence microscopy image of a sporulating cell producing a SpollIE-GFP fusion during chromosome translocation. The upper panel shows the DNA stained with DAPI (blue) and the GFP signal, and the lower panel shows in addition the membranes stained with FM 4-64 (red). SpollIE forms a focus (green) at septal midpoint, where the chromosome is trapped. (C) SpollIE visualized by super-resolution microscopy (PALM) in living cells with thicker polar septa. SpollIE forms two foci (dual foci), which are separated by a distance equivalent to the septal thickness, indicating that one cluster is present at one side of the septum and the other at the opposite side. Reproduced from [101]. (D) Model for the organization and function of the SpollIE translocation complex at the septal midpoint. SpollIE forms two side-by-side channels spanning both septal membranes (red lines), thereby allowing the simultaneous transport of both arms of the chromosome from the mother cell (MC) to the forespore (FS). Translocation is powered by SpollIE motor domains at the mother-cell side of the septum (green circles), which are activated to export the chromosome to the forespore. Forespore motor domains (red circles) remain inactive. (E) Cryo-electron microscopy of a wildtype sporulating cell (top), and of a spollIE mutant (bottom). Membranes are annotated as follows: forespore membrane, pink; mother-cell membrane, purple. Chromosome translocation is required to maintain the shape of the forespore. In the absence of chromosome translocation, the forespore appears deflated. Reproduced with permission from [100].

the forespore during engulfment [132-139], the synthesis of the peptidoglycan cortex [140], and the assembly of the proteinaceous coat $[20,141]$, to name a few.

\section{HISTORICAL CONTINGENCIES}

Sporulation in $B$. subtilis is one of the most wellunderstood developmental processes, but there are still gaps in our understanding, which are due in part to the historical contingencies of sporulation research. Much of the sporulation research performed so far has focused on understanding the role of different developmental genes in spore formation. The definition of spo genes-those that, when mutated, impair the ability to form spores without affecting vegetative growth-has likely biased our understanding of sporulation, as it necessarily excluded all the essential genes and non-essential genes that are also required for optimal vegetative growth. It has therefore remained unclear whether essential housekeeping proteins involved in central metabolism, redox reactions, protein folding, and translational regulation play a significant role in assembling the spore, and if so, if they are required in a specific cell or during a specific stage of sporulation. Recent high-throughput studies have identified vegetative proteins that likely play a role in sporulation $[142,143]$. Genetic tools to interfere with the function of specific proteins in a precise, cell- and developmental stage-specific manner during spore formation have also recently been developed (Fig. 6C and D) [113], and these present a promising new approach for understanding the role played by these and other vegetative proteins during endospore formation. Although many facets of sporulation remain unclear, new technologies and innovative approaches will continue to advance our knowledge of this remarkable process.

A more general aspect of endospore formation that remains poorly studied is how the process functions in different species. Endospore formation occurs in a broad range of bacterial species that belong to an ancient and exceptionally diverse bacterial phylum, the Firmicutes 
[144]. However, most mechanistic studies on sporulation over the previous 50 years have been done in $B$. subtilis, as this organism is particularly amenable to genetic studies. Placing the focus on a single species has provided us with extraordinarily detailed descriptions of sporulation but, at the same time, has prevented us from fully appreciating the diversity of endospore formation. In recent years, Clostridioides difficile - formerly known as Clostridium difficile - has become a model for endospore formation in anaerobic bacteria. Studies in this organism reveal that, although the general scheme of endospore formation is similar to that of $B$. subtilis, there are mechanistic differences that affect every sporulation stage, from initiation to germination [145-151]. In addition, while B. subtilis and $C$. difficile produce one spore per sporangium, there are some species that can produce two $[152,153]$, and others that can produce multiple spores [154-156], opening the intriguing possibility that the sporulation pathway was coopted as a reproductive strategy in some species, or that sporulation evolved from what was originally a reproductive strategy [157-160]. Clearly, this is a rich and interesting area of future research that will require the development of new culturing techniques and genetic tools to manipulate non-model bacteria. Understanding the diversity

\section{REFERENCES}

1. Cano R, and Borucki M (1995). Revival and identification of bacterial spores in 25- to 40-million-year-old Dominican amber. Science 268(5213): 1060-1064. doi: 10.1126/science.7538699

2. Crichton M (1990). Jurassic Park, 1st ed. Alfred A. Knopf.

3. D'Amelio E, Gentile B, Lista F, and D'Amelio R (2015). Historical evolution of human anthrax from occupational disease to potentially global threat as bioweapon. Environ Int 85: 133-146. doi: 10.1016/j.envint.2015.09.009

4. Ehrenberg CG (1838). Die Infusionsthierchen als vollkommene Organismen. Verlag Von Leopold Voss, Leipzig.

5. Cohn F (1876). Untersuchungen über Bakterien IV. Beiträge zur Biologie der Bazillen. Beitrage zur Biol der Pflanz 249-276.

6. Koch R (1876). Untersuchungen über Bakterien V. Die Aetiologie der Milzbrand-Krankheit, begründent auf die Entwicklungsgeschichte des Bacillus Anthracis. Beitrage zur Biol der Pflanz 277-310.

7. Tyndall J (1877). On heat as a germinicide when discontinuously applied. Proc R Soc 25: 569-570.

8. Knaysi G (1938). Cytology of bacteria. Bot Rev 4: 83-112.

9. Lewis IM (1941). The cytology of bacteria. Bact Rev 5: 181-230.

10. Ernst $P$ (1889). Über Kern- und Sporenbildung in Bakterien. Z Hyg Infect 5: 428-486.

11. Peters WL (1889). Die Organismen des Sauerteigs und ihre Bedeutung für die Brotgährung. Bot Ztg 47: 437-439.

12. Young $E$, and Fitz-James $P$ (1959). Chemical and morphological studies of bacterial spore formation $i$. The formation of spores in Bacillus cereus. J Biphysical Biochem Cytol 6(3): 467-482. doi: 10.1083/jcb.6.3.467

13. Fitz-James $P$ (1960). Participation of the cytoplasmic membrane in the growth and spore formation of Bacilli. J Biohysical Biochem Cytol 8(9): 507-528. doi: 10.1083/jcb.8.2.507 of endospore formation may allow us to address key questions regarding the ecological roles and the evolutionary origin of this fascinating developmental process.

\section{ACKNOWLEDGMENTS}

We thank Jan Böhning for assistance with translation of the Koch and Cohn publications. This work was supported by ERC starting grant 853323.

\section{CONFLICT OF INTEREST}

The authors declare no conflict of interest.

\section{COPYRIGHT}

(C) 2020 Riley et al. This is an open-access article released under the terms of the Creative Commons Attribution (CC BY) license, which allows the unrestricted use, distribution, and reproduction in any medium, provided the original author and source are acknowledged.

Please cite this article as: Eammon P. Riley, Corinna Schwarz, Alan I. Derman and Javier Lopez-Garrido (2020). Milestones in Bacillus subtilis sporulation research. Microbial Cell 8(1): 1-16. doi: 10.15698/mic2021.01.739

14. Fitz-james PC (1962). Morphology of spore development in Clostridium pectinovorum. J Bacteriol 84: 104-114. doi: 10.1128/JB.84.1.104-114.1962

15. Kawata T, Inoue T, and Takagi A (1963). Electron microscopy of spore formation and germination in Bacillus subtilis. Jpn J Microbiol 7(1): 23-41. doi: 10.1111/j.1348-0421.1963.tb00926.x

16. Ohye DF, and Murrell DP (1962). Formation and structure of the spore of Bacillus coagulans. J Cell Biol 14: 111-123. doi: 10.1083/jcb.14.1.111

17. Ryter A (1965). Étude morphologique de la sporulation de Bacillus subtilis. Ann Inst Pasteur 108: 40-60. PMID: 14289982

18. Ryter A, Schaeffer $P$, and lonesco $H$ (1966). Classification cytologique, par leur stade de blocage, des mutants de sporulation de Bacillus subtilis Marburg. Ann Inst Pasteur 110(3): 305-315. PMID: 4955547

19. Piggot PJ, and Coote JG (1976). Genetic aspects of bacterial endospore formation. Bacteriol Rev 40(4): 908-62. 12736. doi: 10.1128/mmbr.40.4.908-962.1976

20. McKenney PT, Driks A, and Eichenberger $P$ (2013). The Bacillus subtilis endospore: assembly and functions of the multilayered coat. Nat Rev Microbiol 11(1): 33-44. doi: 10.1038/nrmicro2921

21. Spizizen J (1958). Transformation of biochemically deficient strains of Bacillus subtilis by deoxyribonucleate. Proc Natl Acad Sci 44(10): 1072-1078. doi: 10.1073/pnas.44.10.1072

22. Takahashi I (1961). Genetic transduction in Bacillus subtilis. Biochem Biophys Res Commun 5(3): 171-175. doi: 10.1016/0006291x(61)90104-8

23. Takahashi I (1963). Transducing phages for Bacillus subtilis. J Gen Microbiol 31: 211-217. doi: 10.1099/00221287-31-2-211

24. Thorne CB (1962). Transduction in Bacillus subtilis. J Bacteriol 83(1): 106-111. doi: 10.1128/jb.83.1.106-111.1962 
25. Taylor MJ and Thorne CB (1963). Transduction of Bacillus licheniformis and Bacillus subtilis by each of two phages. J Bacteriol 86:452-461. doi: 10.1128/JB.86.3.452-461.1963

26. Chamberland C, and Roux E (1883). Sur l'atténuation de la virulence de la bactéride charbonneuse, sous l'influence des substances antiseptiques. Comptes Rendus l'Academie des Sci 96: 1088-1092.

27. Schaeffer $P$, and lonesco H (1960). Contribution a l'étude génétique de la sporogenèse bactérienne. Comptes rendus Hebd des séances I' Académie des Sci 251: 3125-3127.

28. Takahashi I (1965). Transduction of sporogenesis in Bacillus subtilis. J Bacteriol. 89(2): 294-298. doi: 10.1128/jb.89.2.294-298.1965

29. Donovan W, Zheng L, Sandman K, and Losick R (1987). Genes encoding spore coat polypeptides from Bacillus subtilis. J Mol Biol 196(1): 1-10. doi: 10.1016/0022-2836(87)90506-7

30. Hullo M-F, Moszer I, Danchin A, and Martin-verstraete I (2001). CotA of Bacillus subtilis is a copper-dependent laccase. J Bacteriol 183(18): 5426-5430. doi: 10.1128/JB.183.18.5426

31. Schaeffer $P$, lonesco $H$, and Jacob $F$ (1959). Sur le déterminisme génétique de la sporulaiton bactérienne. Comptes rendus Hebd des séances I' Académie des Sci 249: 577-578.

32. Michel J, Cami B, and Schaeffer P (1970). Genetics of sporulation in Bacillus subtilis Marburg. Simp Bact Spores 13-24.

33. Piggot PJ (1973). Mapping of asporogenous mutations of Bacillus subtilis: a minimum estimate of the number of sporulation operons. J Bacteriol 114(3): 1241-1253. 4197271. doi: 10.1128/jb.114.3.12411253.1973

34. Rogolsky M (1969). Chromosomal regions which control sporulation in Bacillus subtilis. Can J Microbiol 15: 787-790. doi: 10.1139/m69-137

35. Trowsdale J, and Smith DA (1975). Isolation, characterization, and mapping of Bacillus subtilis 168 germination mutants. J Bacteriol 123(1): 83-95. 806583. doi: 10.1128/JB.123.1.83-95.1975

36. Vary JC (1975). Properties of temperature-sensitive germination mutants of Bacillus megaterium. J Bacteriol 121(1): 197-203. doi: 10.1128/JB.121.1.197-203.1975

37. Moir A, Lafferty E, and Smith DA (1979). Genetic analysis of spore germination mutants of Bacillus subtilis 168: the correlation of phenotype with map location. J Gen Microbiol 111(1): 165-180. doi: 10.1099/00221287-111-1-165

38. Moir A, and Smith DA (1990). The genetics of bacterial spore germination. Annu Rev Microbiol 44: 531-53. doi: 10.1146/annurev.mi.44.100190.002531

39. Wax R, Freese $E$, and Cashel $M$ (1967). Separation of two functional roles of L-alanine in the initiation of Bacillus subtilis spore germination. J Bacteriol 94(3): 522-529. doi: 10.1128/JB.94.3.522529.1967

40. Foerster HF (1971). Gamma-aminobutyric acid as a required germinant for mutant spores of Bacillus megaterium. J Bacteriol 108(2): 817-823. doi: 10.1128/jb.108.2.817-823.1971

41. Sammons RL, Slynn GM, and Smith DA (1987). Genetical and molecular studies on gerM, a new developmental locus of Bacillus subtilis. J Gen Microbiol 133: 3299-3312. doi: 10.1099/00221287-13312-3299

42. Rodrigues CDA, Ramírez-Guadiana FH, Meeske AJ, Wang X, and Rudner DZ (2016). GerM is required to assemble the basal platform of the SpollIA-SpollQ transenvelope complex during sporulation in Bacillus subtilis. Mol Microbiol 102(2): 260-273. doi: 10.1111/mmi.13457
43. Curiel-quesada E, Setlow B, and Setlow $P$ (1983). Cloning of the gene for $C$ protein, a low molecular weight spore-specific protein from Bacillus megaterium. Proc Natl Acad Sci U S A 80: 3250-3254. doi: 10.1073/pnas.80.11.3250

44. Connors MJ, Mason JM, and Setlow P (1986). Cloning and nucleotide sequencing of genes for three small, acid-soluble proteins from Bacillus subtilis spores. J Bacteriol 166(2): 417-425. doi: 10.1128/jb.166.2.417-425.1986

45. Setlow $P$ (1988). Small, acid-soluble spore proteins of Bacillus species: structure, synthesis, genetics, function, and degradation. Annu Rev Microbiol 42: 319-338. doi: 10.1146/annurev.mi.42.100188.001535

46. Zheng LB, Donovan WP, Fitz-James PC, and Losick R (1988). Gene encoding a morphogenic protein required in the assembly of the outer coat of the Bacillus subtilis endospore. Genes Dev 2(8): 1047-54. doi: 10.1101/gad.2.8.1047

47. Connors MJ, and Setlow P (1985). Cloning of a small, acid-soluble spore protein gene from Bacillus subtilis and determination of its complete nucleotide sequence. J Bacteriol 161(1): 333-339. doi: 10.1128/jb.161.1.333-339.1985

48. Mason JM, and Setlow P (1986). Essential role of small, acidsoluble spore proteins in resistance of Bacillus subtilis spores to UV light. J Bacteriol 167(1): 174-8. doi: 10.1128/jb.167.1.174-178.1986

49. Hackett RH, and Setlow P (1988). Properties of spores of Bacillus subtilis strains which lack the major small, acid-soluble protein. J Bacteriol 170(3): 1403-1404. doi: 10.1128/jb.170.3.1403-1404.1988

50. Sandman K, Losick R, and Youngman P (1987). Genetic analysis of Bacillus subtilis spo mutations generated by Tn917-mediated insertional mutagenesis. Genetics 117(4): 603-617. doi: 10.1128/JB.01343-06

51. Youngman PJ, Perkins JB, and Losick R (1983). Genetic transposition and insertional mutagenesis in Bacillus subtilis with Streptococcus faecalis transposon Tn917. Proc Natl Acad Sci U S A 80(8): 2305-9. doi: 10.1073/pnas.80.8.2305

52. Youngman $P$ (1990). Use of transposons and integrational vectors for mutagenesis and construction of gene fusions in Bacillus species. In: Harwood CR, Cutting SM, editors Mol. Biol. Methods Bacillus, First. John Wiley \& Sons, Chichester, New York, Brisbane, Toronto, Singapore; pp 221-266.

53. Zeigler DR (2002). Integration Vectors for gram-positive bacteria. Bacillus Genet Stock Cent Cat 4: 1-58.

54. Bron S (1990). Plasmids. In: Harwood CR, Cutting SM, editors Mol. Biol. Methods Bacillus, First. John Wiley \& Sons, Chichester, New York, Brisbane, Toronto, Singapore; pp 75-174.

55. Errington J (1990). Gene cloning techniques. In: Harwood CR, Cutting SM, editors Mol. Biol. Methods Bacillus, First. John Wiley \& Sons, Chichester, New York, Brisbane, Toronto, Singapore; pp 175220.

56. Errington J, and Mandelstam J (1986). Use of a lacZ gene fusion to determine the dependence pattern and the spore compartment expression of sporulation operon spoVA in spo mutants of Bacillus subtilis. J Gen Microbiol 132(1986): 2977-2985. doi: 10.1099/00221287-132-11-2977

57. Panzer S, Losick R, Sun D, and Setlow P (1989). Evidence for an additional temporal class of gene expression in the forespore compartment of sporulating Bacillus subtilis. J Bacteriol 171(1): 561564. doi: 10.1128/jb.171.1.561-564.1989

58. Mason JM, Hackett RH, and Setlow P (1988). Regulation of expression of genes coding for small, acid-soluble proteins of Bacillus subtilis spores: studies using lacZ gene fusions. J Bacteriol 170(1): 


\section{9-244. doi: 10.1128/jb.170.1.239-244.1988}

59. De Lencastre $H$, and Piggot PJ (1979). Identification of different sites of expression for spo loci by transformation of Bacillus subtilis. J Gen Microbiol 114(2): 377-389. doi: 10.1099/00221287-114-2-377

60. Illing $N$, Young $M$, and Errington $J(1990)$. Use of integrational plasmid excision to identify cellular localization of gene expression during sporulation in Bacillus subtilis. J Bacteriol 172(12): 6937-6941. doi: 10.1128/jb.172.12.6937-6941.1990

61. Burgess RR, Travers AA, Dunn JJ, and Bautz EKF (1969). Factor stimulating transcription by RNA polymerase. Nature 221(5175): 4346. doi: $10.1038 / 221043 \mathrm{aO}$

62. Travers AA, and Burgess RR (1969). Cyclic Re-use of the RNA polymerase sigma factor. Nature 222(5193): 537-540. doi $10.1038 / 222537 a 0$

63. Pero J, Tjian R, Nelson J, and Losick R (1975). In vitro transcription of a late class of phage SP01 genes. Nature 257: 248-251. doi: $10.1038 / 257248 \mathrm{aO}$

64. Haldenwang WG, and Losick R (1979). A modified RNA polymerase transcribes a cloned gene under sporulaiton control in Bacillus subtilis. Nature 282: 256-260. doi: 10.1038/282256a0

65. Losick R, Youngman P, and Piggot PJ (1986). Genetics of endospore formation in Bacillus subtilis. Annu Rev Genet. 20: 625-669. doi 10.1146/annurev.genet.20.1.625

66. Losick R, and Youngman PJ (1984). Endospore formation in Bacillus. In: Losick R, Shapiro L, editors Microb. Dev. Cold Spring Harbor Lab, Cold Spring Harbor, NY; pp 63-88.

67. Haldenwang WG, Lang N, and Losick R (1981). A sporulationinduced sigma-like regulatory protein from $B$. subtilis. Cell 23(2): 615624. doi: 10.1016/0092-8674(81)90157-4

68. Stragier P, Bouvier J, Bonamy C, and Szulmajster J (1984). A developmental gene product of Bacillus subtilis honologous to the sigma factor of Escherichia coli. Nature 312: 376-378. doi: $10.1038 / 312376 a 0$

69. Trempy JE, Bonamy C, Szulmajster J, and Haldenwang WG (1985). Bacillus subtilis $\sigma$ factor $\sigma^{29}$ is the product of the sporulation-essential gene spollG. Proc Natl Acad Sci U S A 82(12): 4189-92. doi: 10.1073/pnas.82.12.4189

70. Errington J, Fort $P$, and Mandelstam J (1985). Duplicated sporulation genes in bacteria. Implications for simple developmental systems. FEBS Lett 188(2): 184-188. doi: 10.1016/00145793(85)80368-9

71. Stragier P (1986). Comment on "Duplicated sporulation genes in bacteria" by J. Errington, P. Fort and J. Mandelstam (FEBS Letters 188 (1985) 184-188). FEBS Lett 195(1-2): 9-11. doi: 10.1016/00145793(86)80119-3

72. Sun $D$, Stragier $P$, and Setlow $P$ (1989). Identification of a new $\sigma$ factor involved in compartmentalized gene expression during sporulation of Bacillus subtilis. Genes Dev 3: 141-149. doi: 10.1101/gad.3.2.141

73. Karmazyn-Campelli C, Bonamy C, Savelli B, and Stragier P (1989). Tandem genes encoding $\sigma$-factors for consecutive steps of development in Bacillus subtilis. Genes Dev 3(2): 150-157. doi: 10.1101/gad.3.2.150

74. Masuda ES, Anaguchi H, Yamada K, and Kobayashi Y (1988). Two developmental genes encoding $\sigma$ factor homologs are arranged in tandem in Bacillus subtilis. Proc Natl Acad Sci U S A 85(20): 7637-41. doi: 10.1073/pnas.85.20.7637

75. Kroos L, Kunkel B, and Losick R (1989). Switch protein alters specificity of RNA polymerase containing a compartment-specific sigma factor. Science 243(4890): 526-529. doi: $10.1126 /$ science. 2492118

76. Errington J (2003). Regulation of endospore formation in Bacillus subtilis. Nat Rev Microbiol 1(2): 117-26. doi: 10.1038/nrmicro750

77. Hilbert DW, and Piggot PJ (2004). Compartmentalization of gene expression during Bacillus subtilis spore formation. Microbiol Mol Biol Rev 68(2): 234-262. doi: 10.1128/MMBR.68.2.234

78. Tan IS, and Ramamurthi KS (2014). Spore formation in Bacillus subtilis. Environ Microbiol Rep 6(3): 212-225. doi: 10.1111/17582229.12130

79. Higgins D, and Dworkin J (2012). Recent progress in Bacillus subtilis sporulation. FEMS Microbiol Rev 36(1): 131-48. doi: 10.1111/j.15746976.2011.00310.x

80. Eichenberger P, Fujita M, Jensen ST, Conlon EM, Rudner DZ, Wang ST, Ferguson C, Haga K, Sato T, Liu JS, and Losick R (2004). The program of gene transcription for a single differentiating cell type during sporulation in Bacillus subtilis. PLoS Biol 2(10): e328. doi: 10.1371/journal.pbio.0020328

81. Wang ST, Setlow B, Conlon EM, Lyon JL, Imamura D, Sato T, Setlow $P$, Losick $R$, and Eichenberger $P$ (2006). The forespore line of gene expression in Bacillus subtilis. J Mol Biol 358(1): 16-37. doi: 10.1016/j.jmb.2006.01.059

82. Eichenberger $P$ (2012). Genomics and cellular biology of endospore formation. In: Graumann PL, editor Bacillus Cell. Mol. Biol. Second. Caister Academic Press, Norfolk, UK; pp 319-350.

83. Zhu B, and Stülke J (2018). SubtiWiki in 2018: from genes and proteins to functional network annotation of the model organism Bacillus subtilis. Nucleic Acids Res 46: D743-D748. doi: 10.1093/nar/gkx908

84. Karow LM, Glaser P, and Piggot PJ (1995). Identification of a gene, spollR, which links the activation of $\sigma^{\mathrm{E}}$ to the transcriptional activity of $\sigma^{\mathrm{F}}$ during sporulation in Bacillus subtilis. Proc Natl Acad Sci USA 92(6): 2012-2016. doi: 10.1073/pnas.92.6.2012

85. Londoño-Vallejo J a, Fréhel C, and Stragier $P$ (1997). SpollQ, a forespore-expressed gene required for engulfment in Bacillus subtilis. Mol Microbiol 24(1): 29-39. doi: 10.1046/j.13652958.1997.3181680.x

86. Clarke S, Lopez-Diaz I, and Mandelstam J (1986). Use of lacZ gene fusions to determine the dependence pattern of the sporulation gene spollD in spo mutants of Bacillus subtilis. J Gen Microbiol 132(1 986): 2987-2994. doi: 10.1099/00221287-132-11-2987

87. Rong S, Rosenkrantz MS, and Sonenshein AL (1986). Transcriptional control of the Bacillus subtilis spollD gene. J Bacteriol 165(3): 771-9. doi: 10.1128/jb.165.3.771-779.1986

88. Roels S, Driks A, and Losick R (1992). Characterization of spolVA, a sporulation gene involved in coat morphogenesis in Bacillus subtilis. J Bacteriol 174(2): 575-85. doi: 10.1128/jb.174.2.586-594.1992

89. Nicholson WL, Sun DX, Setlow B, and Setlow P (1989). Promoter specificity of sigma G-containing RNA polymerase from sporulating cells of Bacillus subtilis: identification of a group of forespore-specific promoters. J Bacteriol 171(5): 2708-2718. doi: 10.1128/jb.171.5.2708-2718.1989

90. Cutting S, Panzer S, and Losick R (1989). Regulatory studies on the promoter for a gene governing synthesis and assembly of the spore coat in Bacillus subtilis. J Mol Biol 207(2): 393-404. doi 10.1016/0022-2836(89)90262-3

91. Zheng $L$, and Losick $R$ (1990). Cascade regulation of spore coat gene expression in Bacillus subtilis. J Mol Biol 212: 645-660. doi: 10.1016/0022-2836(90)90227-d 
92. Sun D, Fajardo-Cavazos P, Sussman MD, Tovar-Rojo F, CabreraMartinez RM, and Setlow P (1991). Effect of chromosome location of Bacillus subtilis forespore genes on their spo gene dependence and transcription by $E \sigma^{\mathrm{F}}$ : identification of features of good $E \sigma^{\mathrm{F}}$-dependent promoters. J Bacteriol 173(24): 7867-74. doi: 10.1128/jb.173.24.7867-7874.1991

93. Li Z, and Piggot PJ (2001). Development of a two-part transcription probe to determine the completeness of temporal and spatial compartmentalization of gene expression during bacterial development. Proc Natl Acad Sci U S A 98(22): 12538-43. doi: 10.1073/pnas.221454798

94. Wu LJ, and Errington J (1998). Use of asymmetric cell division and spollIE mutants to probe chromosome orientation and organization in Bacillus subtilis. Mol Microbiol 27(4): 777-786. doi: 10.1046/j.13652958.1998.00724.x

95. Sharp MD, and Pogliano K (2002). Role of cell-specific SpollIE assembly in polarity of DNA transfer. Science. 295(5552): 137-9. doi: 10.1126/science. 1066274

96. Becker EC, and Pogliano K (2007). Cell-specific SpollIE assembly and DNA translocation polarity are dictated by chromosome orientation. Mol Microbiol 66(5): 1066-79. doi: 10.1111/j.13652958.2007.05992.x

97. Ptacin JL, Nollmann M, Becker EC, Cozzarelli NR, Pogliano K, and Bustamante C (2008). Sequence-directed DNA export guides chromosome translocation during sporulation in Bacillus subtilis. Nat Struct Mol Biol 15(5): 485-93. doi: 10.1038/nsmb.1412

98. Burton BM, Marquis K a, Sullivan NL, Rapoport T a, and Rudner DZ (2007). The ATPase SpollIE transports DNA across fused septal membranes during sporulation in Bacillus subtilis. Cell 131(7): 130112. doi: 10.1016/j.cell.2007.11.009

99. Marquis KA, Burton BM, Nollmann M, Ptacin JL, Bustamante C, Ben-Yehuda S, and Rudner DZ (2008). SpollIE strips proteins off the DNA during chromosome translocation. Genes Dev 22(13): 1786-95. doi: $10.1101 /$ gad.1684008

100. Lopez-Garrido J, Ojkic N, Khanna K, Wagner FR, Villa E, Endres RG, and Pogliano $K$ (2018). Chromosome translocation inflates Bacillus forespores and impacts cellular morphology. Cell 172(4). doi: 10.1016/j.cell.2018.01.027

101. Shin JY, Lopez-Garrido J, Lee S-HH, Diaz-Celis C, Fleming T, Bustamante $C$, and Pogliano $K$ (2015). Visualization and functional dissection of coaxial paired SpollIE channels across the sporulation septum. Elife 4: e06474. doi: 10.7554/eLife.06474

102. Blaylock B, Jiang X, Rubio A, Moran CP, and Pogliano K (2004). Zipper-like interaction between proteins in adjacent daughter cells mediates protein localization. Genes Dev 18(23): 2916-2928. doi: 10.1101/gad.1252704

103. Doan T, Morlot C, Meisner J, Serrano M, Henriques AO, Moran CP, and Rudner DZ (2009). Novel secretion apparatus maintains spore integrity and developmental gene expression in Bacillus subtilis. PLoS Genet 5(7):e1000566. doi: 10.1371/journal.pgen.1000566

104. Kellner EM, Decatur A, and Moran CP (1996). Two-stage regulation of an anti-sigma factor determines developmental fate during bacterial endospore formation. Mol Microbiol 21(5): 913-924. doi: 10.1046/j.1365-2958.1996.461408.x

105. Sun Y, Sharp MD, and Pogliano K (2000). A dispensable role for forespore-specific gene expression in engulfment of the forespore during sporulation of Bacillus subtilis. J Bacteriol 182(10): 2919-2927. doi: 10.1128/JB.182.10.2919-2927.2000

106. Camp AH, and Losick R (2008). A novel pathway of intercellular signalling in Bacillus subtilis involves a protein with similarity to a component of type III secretion channels. Mol Microbiol 69(2): 402-

\section{7. doi: 10.1111/j.1365-2958.2008.06289.x}

107. Meisner J, Maehigashi T, Andre I, Dunham CM, and Moran CP (2012). Structure of the basal components of a bacterial transporter. Proc Natl Acad Sci 109(14): 5446-5451. doi: 10.1073/pnas.1120113109

108. Levdikov VM, Blagova EV, McFeat A, Fogg MJ, Wilson KS, and Wilkinson AJ (2012). Structure of components of an intercellular channel complex in sporulating Bacillus subtilis. Proc Natl Acad Sci U S A 109(14): 5441-5. doi: 10.1073/pnas.1120087109

109. Rodrigues CDA, Henry X, Neumann E, Kurauskas V, Bellard L, Fichou Y, Schanda P, Schoehn G, Rudner DZ, and Morlot C (2016). A ring-shaped conduit connects the mother cell and forespore during sporulation in Bacillus subtilis. Proc Natl Acad Sci U S A 113(41): 11585-11590. doi: 10.1073/pnas.1609604113

110. Zeytuni N, Hong C, Flanagan KA, Worrall $\amalg$, Theiltges KM, Vuckovic M, Huang RK, Massoni SC, Camp AH, Yu Z, and Strynadka NC (2017). Near-atomic resolution cryoEM structures of the 30 -fold homoligomeric SpollIAG channel essential to spore formation in Bacillus subtilis. Proc Natl Acad Sci USA 114(34): E7073-E7081. doi: 10.1073/pnas.1704310114

111. Meisner J, Wang $X$, Serrano $M$, Henriques AO, and Moran CP (2008). A channel connecting the mother cell and forespore during bacterial endospore formation. Proc Natl Acad Sci U S A 105(39): 15100-5. doi: 10.1073/pnas.0806301105

112. Camp $A H$, and Losick $R$ (2009). A feeding tube model for activation of a cell-specific transcription factor during sporulation in Bacillus subtilis. Genes Dev 23(8): 1014-24. doi: 10.1101/gad.1781709

113. Riley EP, Trinquier A, Reilly ML, Durchon M, Perera VR, Pogliano K, and Lopez-Garrido J (2018). Spatiotemporally regulated proteolysis to dissect the role of vegetative proteins during Bacillus subtilis sporulation: cell-specific requirement of $\sigma^{\mathrm{H}}$ and $\sigma^{\mathrm{A}}$. Mol Microbiol 108(1): 45-62. doi: 10.1111/mmi.13916

114. Griffith KL, and Grossman AD (2008). Inducible protein degradation in Bacillus subtilis using heterologous peptide tags and adaptor proteins to target substrates to the protease ClpXP. Mol Microbiol 70(4): 1012-25. doi: 10.1111/j.1365-2958.2008.06467.x

115. Riley EP, Lopez-Garrido J, Sugie J, Liu RB and Pogliano K (2020). Metabolic differentiation and intercellular nurturing underpin bacterial endospore formation. Science Advances. In press

116. Wu LJ, and Errington J (1994). Bacillus subtilis SpollIE protein required for DNA segregation durng asymmetric cell division. Science 264(5158): 572-575. doi: 10.1126/science.8160014

117. Wu L, and Errington J (1997). Septal localization of the SpollIE chromosome partitioning protein in Bacillus subtilis. EMBO J 16(8): 2161-9. doi: 10.1093/emboj/16.8.2161

118. Bath J, Wu LJ, Errington J, and Wang JC (2000). Role of Bacillus subtilis SpollIE in DNA transport across the mother cell-prespore division septum. Science 290(5493): 995-7. doi 10.1126/science.290.5493.995

119. Cattoni DI, Thakur S, Godefroy C, Le Gall A, Lai-Kee-Him J, Milhiet P-E, Bron P, and Nöllmann M (2014). Structure and DNA-binding properties of the Bacillus subtilis SpolIIE DNA translocase revealed by single-molecule and electron microscopies. Nucleic Acids Res 42(4): 2624-36. doi: 10.1093/nar/gkt1231

120. Cattoni DI, Chara O, Godefroy C, Margeat E, Trigueros S, Milhiet $\mathrm{P}-\mathrm{E}$, and Nöllmann M (2013). SpollIE mechanism of directiona translocation involves target search coupled to sequence-dependent motor stimulation. EMBO Rep 14(5): 473-9. doi: 10.1038/embor.2013.39

121. Liu N, Chistol G, and Bustamante C (2015). Two-subunit DNA 
escort mechanism and inactive subunit bypass in an ultra-fast ring ATPase. Elife 4: 1-20. doi: 10.7554/eLife.09224.001

122. Liu N, Chistol G, Cui Y, and Bustamante C (2018). Mechanochemical coupling and bi-phasic force-velocity dependence in the ultra-fast ring ATPase SpollIE. Elife 7: e32354. doi: 10.7554/elife. 32354

123. Sharp MD, and Pogliano K (1999). An in vivo membrane fusion assay implicates SpollIE in the final stages of engulfment during Bacillus subtilis sporulation. Proc Natl Acad Sci U S A 96(25): 14553-8. doi: $10.1073 /$ pnas.96.25.14553

124. Fleming TC, Shin JY, Lee SH, Becker E, Huang KC, Bustamante C, and Pogliano K (2010). Dynamic SpollIE assembly mediates septal membrane fission during Bacillus subtilis sporulation. Genes Dev 24: 1160-1172. doi: 10.1101/gad.1925210

125. Fiche J-B, Cattoni DI, Diekmann N, Langerak JM, Clerte C, Royer C a, Margeat E, Doan T, and Nöllmann M (2013). Recruitment, assembly, and molecular architecture of the SpollIE DNA pump revealed by superresolution microscopy. PLoS Biol 11(5): e1001557. doi: 10.1371/journal.pbio.1001557

126. Ben-Yehuda S, Rudner DZ, and Losick R (2003). Assembly of the SpollIE DNA translocase depends on chromosome trapping in Bacillus subtilis. Curr Biol 13(24): 2196-2200. doi: 10.1016/j.cub.2003.12.001

127. Besprozvannaya M, Pivorunas VL, Feldman Z, and Burton BM (2013). SpollIE protein achieves directional DNA translocation through allosteric regulation of ATPase activity by an accessory domain. J Biol Chem 288(40): 28962-28974. doi: 10.1074/jbc.M113.484055

128. Chara O, Borges A, Milhiet PE, Nöllmann M, and Cattoni DI (2018) Sequence-dependent catalytic regulation of the SpollIE motor activity ensures directionality of DNA translocation. Sci Rep. 8(1): 1-10. doi: 10.1038/s41598-018-23400-8

129. Barák I, Muchová K, and Labajová N (2019). Asymmetric cell division during Bacillus subtilis sporulation. Future Microbiol 14(4): 353-363. doi: 10.2217/fmb-2018-0338

130. Errington J, and $\mathrm{Wu} \mathrm{LJ}$ (2017). Cell cycle machinery in Bacillus subtilis. In: Löwe J, Amos LA, editors Prokaryotic Cytoskelet. Springer International Publishing; pp 67-101.

131. Khanna K, Lopez-Garrido J, Sugie J, Pogliano K, and Villa E (2020). Asymmetric localization of the cell division machinery during Bacillus subtilis sporulation. bioRxiv. doi: 10.1101/2020.07.22.216184

132. Abanes-De Mello A, Sun YL, Aung S, and Pogliano K (2002). A cytoskeleton-like role for the bacterial cell wall during engulfment of the Bacillus subtilis forespore. Genes Dev 16: 3253-3264. doi: 10.1101/gad.1039902

133. Broder $\mathrm{DH}$, and Pogliano $\mathrm{K}$ (2006). Forespore engulfment mediated by a ratchet-like mechanism. Cell 126(5): 917-28. doi: 10.1016/j.cell.2006.06.053

134. Morlot C, Uehara T, Marquis K a, Bernhardt TG, and Rudner DZ (2010). A highly coordinated cell wall degradation machine governs spore morphogenesis in Bacillus subtilis. Genes Dev 24(4): 411-22. doi: 10.1101/gad.1878110

135. Ojkic N, López-Garrido J, Pogliano K, and Endres RG (2016). Cellwall remodeling drives engulfment during Bacillus subtilis sporulation. Elife 5: e18657. doi: 10.7554/eLife.18657

136. Chastanet $A$, and Losick $R$ (2007). Engulfment during sporulation in Bacillus subtilis is governed by a multi-protein complex containing tandemly acting autolysins. Mol Microbiol 64(1): 139-52. doi: 10.1111/j.1365-2958.2007.05652.x

137. Ojkic N, López-Garrido J, Pogliano K, and Endres RG (2014). Bistable forespore engulfment in Bacillus subtilis by a zipper mechanism in absence of the cell wall. PLoS Comput Biol 10(10):

\section{e1003912. doi: 10.1371/journal.pcbi.1003912}

138. Khanna K, Lopez-Garrido J, Zhao Z, Watanabe R, Yuan Y, Sugie J, Pogliano K, and Villa E (2019). The molecular architecture of engulfment during Bacillus subtilis sporulation. Elife 8: 1-22. doi: 10.7554/eLife. 45257

139. Khanna K, Lopez-garrido J, and Pogliano K (2020). Shaping an endospore: architectural transformations during Bacillus subtilis sporulation. Annu Rev Microbiol 74: 361-386. doi: 10.1146/annurevmicro-022520-074650

140. Popham DL, and Bernhards CB (2015). Spore peptidoglycan. Microbiol Spectr 3(6): 1-21. doi: 10.1128/microbiolspec.TBS-00052012

141. Driks $A$, and Eichenberger $P$ (2016). The spore coat. ASMscience 4(2): 1-19. doi: 10.1128/microbiolspec.TBS

142. Meeske AJ, Rodrigues CDA, Brady J, Lim HC, Bernhardt TG, and Rudner DZ (2016). High-throughput genetic screens identify a large and diverse collection of new sporulation genes in Bacillus subtilis. PLoS Biol 14(1): e1002341. doi: 10.1371/journal.pbio.1002341

143. Koo BM, Kritikos G, Farelli JD, Todor H, Tong K, Kimsey H, Wapinski I, Galardini M, Cabal A, Peters JM, Hachmann AB, Rudner DZ, Allen KN, Typas A, and Gross CA (2017). Construction and analysis of two genome-scale deletion libraries for Bacillus subtilis. Cell Syst 4(3): 291-305.e7. doi: 10.1016/j.cels.2016.12.013

144. Galperin MY (2013). Genome diversity of spore-forming Firmicutes. Microbiol Spectr 1(2): TBS-0015-2012. doi: 10.1128/microbiolspec.tbs-0015-2012

145. Al-Hinai MA, Jones SW, and Papoutsakis ET (2015). The Clostridium sporulation programs: diversity and preservation of endospore differentiation. Microbiol Mol Biol Rev 79(1): 19-37. doi: 10.1128/MMBR.00025-14

146. Fimlaid KA, Bond JP, Schutz KC, Putnam EE, Leung JM, Lawley TD, and Shen $A$ (2013). Global analysis of the sporulation pathway of Clostridium difficile. PLoS Genet 9(8). doi: 10.1371/journal.pgen.1003660

147. Ribis JW, Fimlaid KA, and Shen A (2018). Differential requirements for conserved peptidoglycan remodeling enzymes during Clostridioides difficile spore formation. Mol Microbiol (617): 02. doi: 10.1111/mmi.14090

148. Ribis JW, Ravichandran P, Putnam EE, Pishdadian K, and Shen A (2017). The conserved spore coat protein SpoVM is largely dispensable in Clostridium difficile spore formation. mSphere 2(5): e00315-17. doi: 10.1128/mSphere.00315-17

149. Fimlaid KA, and Shen A (2015). Diverse mechanisms regulate sporulation sigma factor activity in the Firmicutes. Curr Opin Microbiol 24: 88-95. doi: 10.1016/j.mib.2015.01.006

150. Dembek M, Kelly A, Barwinska-Sendra A, Tarrant E, Stanley WA Vollmer D, Biboy J, Gray J, Vollmer W, and Salgado PS (2018). Peptidoglycan degradation machinery in Clostridium difficile forespore engulfment. Mol Microbiol 0-2. doi: 10.1111/mmi.14091

151. Serrano M, Crawshaw AD, Dembek M, Monteiro JM, Pereira FC, Pinho MG, Fairweather NF, Salgado PS, and Henriques AO (2016). The SpollQ-SpolIIAH complex of Clostridium difficile controls forespore engulfment and late stages of gene expression and spore morphogenesis. Mol Microbiol 100(1): 204-228. doi: 10.1111/mmi.13311

152. Smith LDS (1970). Clostridium oceanicum, sp. n., a sporeforming anaerobe isolated from marine sediments. J Bacteriol 103(3): 811-813. doi: $10.1128 / j b .103 .3 .811-813.1970$

153. Chapman GB, Herk AS van, and Eguía JM (1992). The occurrence of disporous Bacillus thuringiensis cells. Antonie Van Leeuwenhoek 


\section{1(4): 265-268. doi: 10.1007/BF00713934}

154. Duda VI, Lebedinsky A V., Mushegjan MS, and Mitjushina LL (1987). A new anaerobic bacterium, forming up to five endospores per cell -Anaerobacter polyendosporus gen. et spec. nov. Arch Microbiol 148(2): 121-127. doi: 10.1007/BF00425359

155. Kunstýř I, Schiel R, Kaup FJ, Uhr G, and Kirchhoff H (1988). Giant Gram-negative noncultivable endospore-forming bacteria in rodent intestines. Naturwissenschaften 75(10): 525-527. doi: 10.1007/BF00361293

156. Clements KD, Sutton DC, and Choat JH (1989). Occurrence and characteristics of unusual protistan symbionts from surgeonfishes (Acanthuridae) of the Great Barrier Reef, Australia. Mar Biol 102(3): 403-412. doi: 10.1007/BF00428493
157. Angert ER, Hutchison EA, and Miller DA (2014). Sporulation in bacteria: beyond the standard model. Bact Spore from Mol to Syst 87-102. doi: 10.1128/microbiolspec.TBS-0013-2012

158. Angert ER, and Losick RM (1998). Propagation by sporulation in the guinea pig symbiont Metabacterium polyspora. Proc Natl Acad Sci U S A 95(17): 10218-10223. doi: 10.1073/pnas.95.17.10218

159. Angert ER, Brooks AE, and Pace NR (1996). Phylogenetic analysis of Metabacterium polyspora: Clues to the evolutionary origin of daughter cell production in Epulopiscium species, the largest bacteria. J Bacteriol 178(5): 1451-1456. doi: 10.1128/jb.178.5.1451-1456.1996

160. Angert ER, and Clements KD (2004). Initiation of intracellular offspring in Epulopiscium. Mol Microbiol 51(3): 827-835. doi: 10.1046/j.1365-2958.2003.03869.x 